\title{
The pharmacological potentials of Musa paradisiaca Linn.
}

\author{
Ridwan Olamilekan Adesola \\ Department of Veterinary Medicine, University of Ibadan, Ibadan 900001, Nigeria \\ *Email: radesola758@stu.ui.edu.ng
}

\section{ARTICLE HISTORY}

Received: 24 December 2020

Accepted: 15 March 2021

Available online

Version 1: 18 August 2021

Version 2: 05 February 2022

\section{KEYWORDS}

Non-communicable diseases

Musa paradisiaca

Nutritional values

Phytochemical screening

Pharmacological potentials

\begin{abstract}
Musa paradisiaca Linn. (Plantain or cooking banana) is among the major crops that are being cultivated by farmers and serve as the main food crop for both animals and humans in some parts of the world. It shows several beneficial properties. In traditional medicine, the fruits in addition to the other parts of the plant such as the stalk, peel, pulp and leaf are used to treat different diseases in humans. This review presents the scientific information on the pharmacological potentials, possible nutritional values and phytochemicals of this Musa species. It is a source of carbohydrate that can easily be digestible and also provides vital vitamins like vitamin $\mathrm{B}$ complex, vitamin $\mathrm{C}$ and a lot of minerals like potassium ( $\mathrm{K}$ ), calcium (Ca) and magnesium $(\mathrm{Mg}$ ) etc. Most of the in vitro studies, in vivo (animal model) studies and clinical trials, propose that innumerable banana and plantain parts have been utilized in traditional medicine for the treatment of countless non-communicable diseases like diabetes, cancer, hypertension, atherosclerosis, ulcers, urolithiasis and Alzheimer's infection. Also, this review reports the phytocompounds isolated through the use of different solvents for extraction of the plant's parts. A comprehensive assessment of the biological activities of different extracts is included and possible mechanisms and phytochemicals involved have been correlated.
\end{abstract}

\section{Introduction}

Musa paradisiaca Linn. often referred to as plantain or cooking banana is an herbaceous flower-producing plant. It is a native to India and the southern part of Asia but at present, it has been grown in virtually all subtropical and tropical regions of Africa as well as Nigeria. Nigeria produced over 2.11 million metric tons of plantains per annum which contribute extensively to the sustenance of subtropical native populations (1). Without any doubt, banana is known to be among the cheapest, widespread and beneficial food in the entire humid and temperate region of the world, with a reaped area of roughly 10 million per hectare (2).

M. paradisiaca is in Musaceae family which made up of three genera, Musa, Ensete and Musella. Musa is the largest group among the three genera, with about 35 species that include Musa acumiata, Musa balbisiana and Musa sapietum etc. Musa species are divided into different divisions. According to latest DNA work, there are three divisions: Musa (with 22 chromosomes), Callimusa (with 20 chromosomes) and Ingentimusa (with 14 chromosomes).

M. paradisiaca grows up in length to about $9 \mathrm{~m}$, with yellowish or greenish unsown moon-shaped fruits in a bunch form, up to $7 \mathrm{~cm}$ long based on species and available nutrients in the soil $(3,4) . M$. paradisiaca is pollinated by wind which propagates principally by seeds on the long narrow spikes glowing above the vegetation. The growth of $M$. paradisiaca in compacted soils is more compared to any other herbaceous plants. It can be found copious alongside paths, roadside, riverbank and other regions with smooth soil. This plant can as well be found in savanna and the midst of crops as a weed.

In South and Central America, Asia and Africa, $M$. paradisiaca provides food containing mainly starch of significance in both humans and animals (5). $M$. paradisiaca provides over 200 calories (food energy) per day for almost 600 million people in Africa.

Recently, there have been indications of developing importance in plants as a substantial source of first-hand medicines. In developing countries like Nigeria, a large number of people have recourse to the use of various parts of plant for the treatment of ailments. Possibly because the world has shifted to the utilization of natural resources other than man-made drugs or the high price of conventional services provided by health professionals (6). A lot of drugs produced today are derived from plant sources, for instance, digoxin is synthesized from Digitalis lanata, quinidine with

(c) Adesola (2021). This is an open-access article distributed under the terms of the Creative Commons Attribution License, which permits unrestricted use, distribution and reproduction in any medium, provided the original author and source are credited (https://creativecommons.org/licenses/by/4.0/) 
quinine are from Chinchona officinalis, vinblastine with vincristine is from Catharanthus spp., atropine is from Atropa spp., codeine, as well as morphine, are from Papaver spp. (7).

The therapeutic and economic significance of $M$. paradisiaca has stimulated numerous ethnopharmacological and ethnobotanical studies which lead to the finding of many fascinating properties of plant parts. By and large, these properties of the plants are built on how native people utilize them medicinally $(8,9)$.

Musa paradisiaca contains many nutrients such as bioactive metabolites and minerals which have been used for the treatment and management of several ailments. For instance, the anti-ulcerogenic ability was shown by unripe $M$. paradisiaca peels and fruits when fermented then extracted with water (10, 11). Also, hydroxyanigorufone from $M$. paradisiaca displayed potential chemopreventive properties for cancer (12). Additionally, $12.54 \%$ of dietary fiber is present in plantain inflorescence and 12 polyphenols were seen and quantified from the methanolic extract of plantain inflorescence. These polyphenols demonstrated their potentials as antidiabetic and cardiovascular diseases protector (13). Biologically active molecules are held by dietary fiber from plantain inflorescence after its identification as a matrix (14). These biologically active molecules are always released in digestion with probiotic bacteria which helps in fermentation, all these have advantageous effects on gastrointestinal health and decreasing the exposure to colon cancer $(15,16)$. This review presents an attempt at the various nutritional values and pharmacological mechanisms, as well as phytochemical properties, reported so far from $M$. paradisiaca.

\section{Results and Discussion}

\section{Nutritional values}

Musa paradisiaca Linn. is studied to be the largest herb produced in the world, and it is planted in several developing and developed countries around the world. Banana is classified as important energyproviding food. Proximate analysis was done on $M$. paradisiaca and shown the presence of many nutrients like carbohydrates (23 gm), dietary fiber (2.6 gm), protein (1.1 gm), lipids (0.3 gm), as well as minerals such as Potassium-K, Magnesium-Mg, Phosphorus-P, Calcium-Ca, Sodium-Na, Zinc-Zn and Iron-Fe, then, water-soluble vitamins such as Thiamine (vitamin B1), Riboflavin (vitamin B2), Niacin (vitamin B3), Ascorbic acid (vitamin C) and Folic acid (17-19).

After citrus, banana is the major fruit producer, which contributes to $16 \%$ of total fruit produced in the world. There are abundant amount of sugars, vitamins, pectin, cellulose, hemicellulose and lignin in banana peel and it can be recycled as calves' feed, biogas' material base, alcohol production and extraction of protein. The leaves are a good source of lignocellulose and have varieties of uses from feed to the wrapping of food products and even as roofing material in banana growing places. Fiber from the pseudo-stem can be exploited as bio-degradable binding ropes. There can be the utilization of the pith as a food and color absorber after thorough processing. Apart from starch, pharmaceutical industries make use of the juice because of its pharmaceutical properties (20).

\section{Phytochemical screening}

Phytochemical screening showed the presence of glycoside, oxalate, ascorbic acid, flavonoid, phytic acid, alkaloid, vitamin A, benzoic acid and steroid in banana extracts $(17,21)$. Solvents such as chloroform, acetone, ethyl acetate, ethanol, methanol and water were used by researchers to extract different parts of banana by maceration process and showed the presence of several phytochemicals. The phytochemical screening of banana extracted with ethanol and methanol showed the presence of certain secondary metabolites like alkaloid, saponin, flavonoid, steroid, tannin, xanthoprotein and glycoside (22), (Table 1).

\begin{tabular}{llllll} 
Table 1. phytochemical substances in Musa paradisiaca \\
\hline Extract & Yield(\%) & Glycosides & Phenols & Flavonoids & Saponins \\
\hline $\begin{array}{l}\text { Tepal } \\
\text { methanol }\end{array}$ & 5.87 & ++ & ++ & + & + \\
$\begin{array}{l}\text { Tepal } \\
\begin{array}{l}\text { Ethanol } \\
\text { Tepal }\end{array}\end{array}$ & 5.38 & ++ & ++ & + & + \\
$\begin{array}{l}\text { Aqueous } \\
\text { Skin }\end{array}$ & 5.09 & + & + & ++ & - \\
Flesh & 19.49 & + & + & ++ & - \\
\hline & 28.86 & + & + & + & - \\
\hline
\end{tabular}

Key:++= present in abundance.+= present.-= Absent ND; not determined. Reference [59]

Apart from phytochemical screening of $M$. paradisiaca, isolation of several compounds were reported earlier (58).

\section{Pharmacological potentials}

Many potential activities of $M$. paradisiaca had been discovered by researchers. However, its mechanism of action needs to be comprehended and recognized for prospective use in humans. With this, various activities of $M$. paradisiaca are alighted and discussed below.

\section{Antidiabetic Activity}

Diabetes also referred to as hyperglycemia is described generally as a disease with a rise in blood glucose level higher than the average level, due to the inability of the body to metabolize glucose well. Diabetes mellitus is divided into type 1 diabetes mellitus which is insulin-dependent and type 2 which is non-insulin-dependent. Type 1 is manifested due to the destruction of pancreatic beta cells which leads to the release of low insulin into the blood and it can be regulated by the administration of insulin (23). Whereas type 2 occurs when insulin is not used properly by the body or the body reaction with insulin production is reduced (24).

There are several studies on the effect of $M$. paradisiaca on diabetic activity both in vitro and in vivo studies. In a study the evaluation had been conducted on the effects of $M$. paradisiaca leaf, fruit and peel, extracted with hydroethanolic solvent as an 
antihyperglycemic in nicotinamide (NA) and streptozotocin (STZ) induced diabetic rats and described possible mechanism of actions.

In this study, anti-inflammatory efficacy of $M$. paradisiaca leaf, fruit and peel was endorsed due to reduction in increased serum Interleukin 6 (IL-6) and tumor necrotic factor-alpha (TNF- $\alpha$ ) in NA and STZ induced diabetic rats treated with hydroethanolic extract of $M$. paradisiaca leaf, fruit and peel. It worth mentioning that inflammatory cytokines like IL-1 $\beta$ and IL- 6 were released as a result of TNF- $\alpha$ which is a potent proinflammatory cytokine secreted primarily from myeloid cells through the activation of nuclear factor kappa-light-chain-enhancer of activated B cells $(\mathrm{NF}-\mathrm{kB})$ and Mitogen-activated protein (MAP) kinases (25). Also, antagonist activity was stimulated by TNF$\alpha$ towards insulin because of its ability to enlarge the insulin receptor substrate-1 (IRS-1) and insulin receptor phosphorylation (IRP) on residues of threonine or serine (26). Besides, activation of phosphatidylinositide 3-kinase (PI3K) and protein kinase $\mathrm{B}(\mathrm{PKB})$ were prevented by alteration of IRS and IRP on threonine or serine, which decreases the phosphorylation of tyrosine residues through protein kinase $\mathrm{C}(\mathrm{PKC}), \mathrm{NF}-\kappa \mathrm{B}$, and a regulatory protein kinase $(\mathrm{I} \kappa \kappa \beta) \quad(27-29)$. This decrease in phosphorylation of tyrosine residues causes resistance to insulin (30). TNF- $\alpha$ as well downregulate the messenger RNA (mRNA) levels of adipocyte complement-related protein of 30kDa (Acrp30) [31], which leads to the maintenance of homeostasis of lipid and peripheral glucose $(32,51)$. TNF- $\alpha$ also significantly increases fatty acid (FFA) release and lipolysis, through a reduction in lipid dropletassociated protein (perilipin) expression (33) and decreased expression of Gi protein (34) which further enhances the impaired insulin signal transduction pathway and glucose uptake (33). About the decrease in serum FFA level, there was an increase in the expression of adipose tissue PPARc, glucose transporter type 4 (GLUT4), Acrp30 and insulin receptor $\beta$-subunit due to the treatment of NA and STZ induced diabetic rats with $M$. paradisiaca leaf, fruit and peel extracted with hydroethanolic solvent (55).

The $M$. paradisiaca leaf, fruit and peel extracted with hydroethanolic solvent were used as a supplement for diabetic-induced rats and it downregulated the adipose tissue-specific factor (resistin) expression significantly. Therefore, the potential of Musa paradisiaca as an antidiabetic in this present study could be linked to its resistinmodulating effect.

\section{Antihypertensive Activity}

Hypertension is a physiological state in which the blood pressure is high (35). Persistent hypertension has been associated with numerous cardiovascular diseases (CVD), such as stroke, heart attack and heart failure (36). Likewise, inflammation of the heart resulting from oxidative stress is considered the major cause of CVD (37). The Renin-angiotensin system (RAS) is a hormone system that plays a vital role in the regulation of fluid balance, blood pressure (BP) and salt and in the pathophysiology of CVD, like congestive heart failure (CHF), hypertension and heart attack (38). Renin produces angiotensin-I from angiotensinogen and then, angiotensin-I is converted to angiotensin- II, a potent vasoconstrictor by the angiotensin-I converting enzyme (ACE) (39). $M$. paradisiaca have been reportedly used in folk medicine for the management or prevention of hypertension, there is a shortage of information on whether the peels (unripe, ripe, and over-ripe) constituting a waste problem may exert antihypertensive property. The antihypertensive potentials of the extracts were evaluated by characterizing the interaction of the aqueous extract of the peels with ACE which is considered to be useful in therapeutic approach for management or treatment of high BP. The high inhibitory effects of the water-extractable phytochemicals could have added to the observed medicinal properties of the peels.

Furthermore, evaluation had been conducted on the antihypertensive effect of ripe banana pulp (50 $\mathrm{gm} / \mathrm{rat} /$ day) in deoxycorticosterone enanthate (DOC, $25 \mathrm{mg} / \mathrm{rat}$ ) induced hypertensive rats. This rise the serotonin level to mediate natriuretic effects because of the high tryptophan and carbohydrate content of ripe banana pulp (40). Similarly, Orie reported that the effect of aqueous extract of plantain was established based on its concentration-dependent hypotensive $(\mathrm{CDH})$ effect on norepinephrine and potassium chloride $(\mathrm{KCl})$ contracted aortic rings and portal vein sequestered from rat (41).

With this, afterward, $M$. paradisiaca could be used for the development of nutraceuticals in hypertension management and/or prevention of hypertension.

\section{Anti-atherosclerotic Activity}

It has been reported that $M$. paradisiaca inhibits in vitro cholesterol crystallization. In this report, $M$. paradisiaca peel extract in rats that were induced by atherosclerosis diet exhibited anti-atherosclerotic effects, due to the presence of ascorbic acid, dopamine and other anti-oxidants in $M$. paradisiaca peel (42). Studies are on the defensive role of $M$. paradisiaca peel extract $(100 \mathrm{mg} / \mathrm{kg})$ for 10 consecutive days in diet-induced atherosclerosis and thyroid dysfunction in rats. Therefore, the defensive role of $M$. paradisiaca peels was established against atherosclerosis induced by diet and thyroid dysfunction in the study $(43,56)$ (Fig. 1).

An atherogenic diet consisting of cholesterol (4\%), cholic acid (1\%) and 2-thiouracil (CCT) (0.5\%) were given to Wistar albino male rats for 14 days to induce atherosclerosis. There was an increase in glucose, serum lipids and tissue lipid peroxidation in rats that were fed with only a CCT diet and led to a parallel reduction in levels of thyroxine (T4) and triiodothyronine (T3), insulin and high-density lipoprotein cholesterol. The histological pathological observations like, fatty cyst, fatty liver with vacuolated hepatocytes and nucleus that was pushed to peripheral and increased myocardiocytes girth and slight damage in renal tissues were seen in these rats. However, most of the histopathological and biochemical alterations that were caused by the CCT 


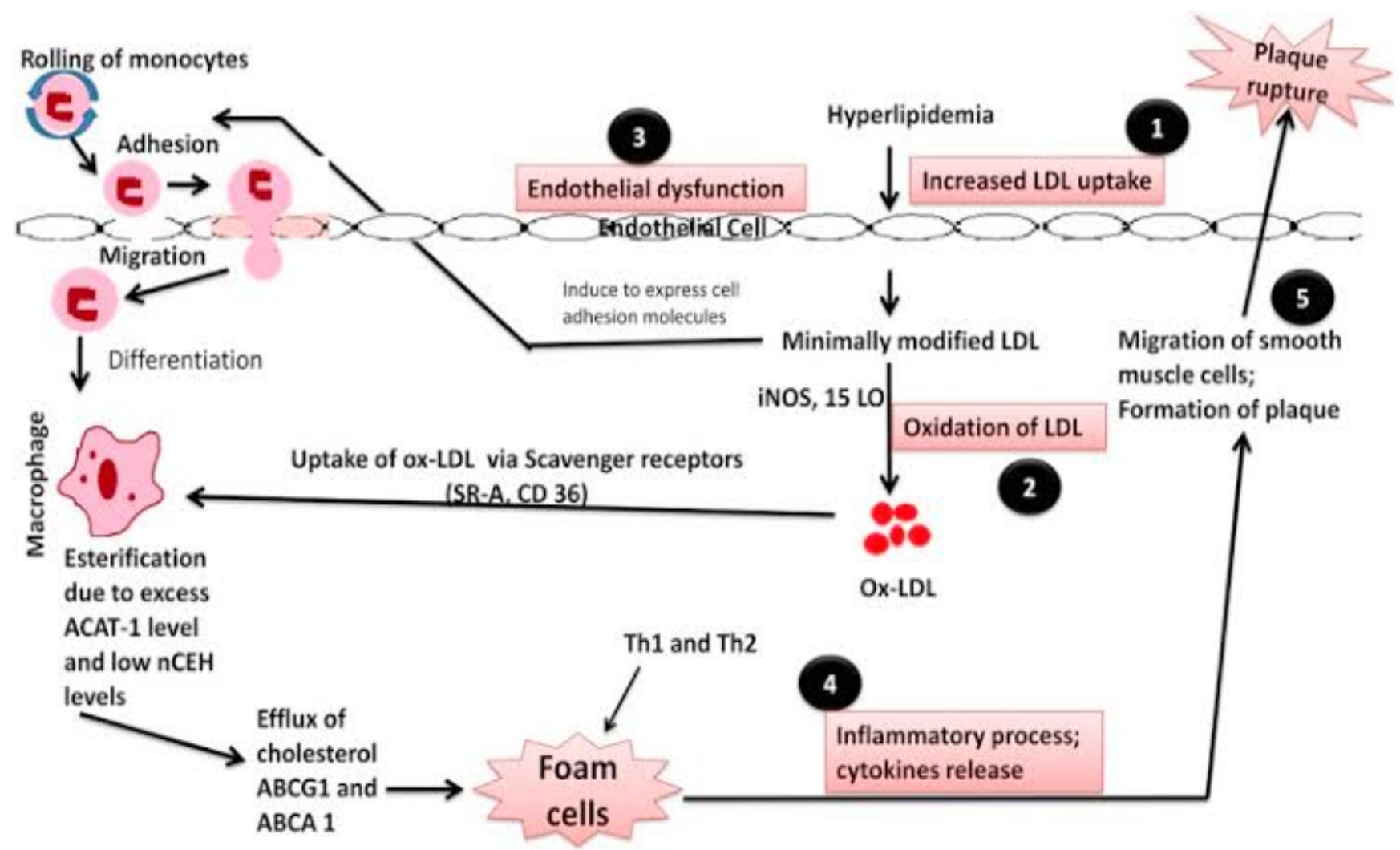

Fig. 1. Pathophysiology of atherosclerosis (56).

diet were inhibited after concurrent treatment with M. paradisiaca peel's extract.

\section{Anticancer activity}

Cancer (Tumor or Malignance) is one of the groups of diseases that cause progressive death to the body across the globe. With this, much attention of scientists has been drawn to the discovery of any potential anticancer agents in both non-edible and edible plants, for use in humans in the future. Among many beneficial medicinal plants screened for anticancer agents, the banana is one of them (44).

The possibility of developing some cancer like colorectal cancer (CRC) is usually linked to eating an unhealthy diet that mainly lacks nutrients like dietary fiber and antioxidants. The conception of dietary fiber and antioxidants is gaining attention in the management and prevention of CRC (44). In this context, a primary study was carried out to screen various residues in agro-industries and find out that plantain inflorescence (PI) was a good source of dietary fiber and antioxidants (45). In this study, HT29 colon cancer cells were used to authenticate the efficacy of PI extracted with methanol (PIMET) as an anticancer agent and outline the possible mechanisms pathway in which anticancer properties are achieved. The cytotoxic effects (CE) of PIMET were determined by colorimetric assays such as 3-(4, 5-dimethylthiazol2-yl)-2, 5-diphenyltetrazolium bromide (MTT) assay and lactate dehydrogenase (LDH) release assay. The action of enzyme succinate dehydrogenase (SDH), Nicotinamide adenine dinucleotide (NADH) and Nicotinamide adenine dinucleotide phosphate (NADPH) that occurs in and outside mitochondria respectively are caused by cellular reduction of
MTT. For this reason, MTT can only be reduced by the population of live cells. While LDH release assay is based on a leak out of cells of cytosol's LDH with damaged membranes. The MTT assay revealed that among the extracts of PI, extraction with methanol had the best CE against HT29 cells. The CE of the extracts increased based on a concentration-dependent manner but PIMET exhibited better cytotoxic activity as it inhibited $50 \%$ cell growth. This was also confirmed by the LDH release assay. Following the result from the MTT assay, the viability and membrane integrity of HT29 colon cancer cells reduced significantly with the increase in the concentration of PIMET (45). This study showed that PIMET is rich in micronutrients like polyphenols, gallic acid, catechol, syringic acid and ferulic acid. The reduction of HT29 colon cancer cells treated with PIMET may be linked to its higher phenolic content, as reported that phenolic compounds have anticancer activity against cancer cells. Similarly, the anticancer activities of gallic acid, catechol, syringic acid and ferulic acid had also been reported on several cancer cell lines available (4648).

Progressively, PIMET has effects on the celldivision cycle (cell cycle). Normal cells usually transmute into cancer cells when proteins involved in maintaining the cell-division cycle fail to appropriately progress from one cell cycle phase to the next. The rate of replication of cancer cells is further than the normal which tightly regulates the limits of the cell division cycle.

As PIMET concentration increased, there were significant changes in the distribution of cells in all 
three phases of HT29. It was prominent that the number of G2/M phase cells increased, while the number of $\mathrm{G} 0 / \mathrm{G} 1$ phase cells decreased. But, inhibition of HT29 cells increased in number in G2/M phase cells after treated with PIMET (50).

In the same vein, proteomics of proteins in HT29 cells revealed that exposure of PIMET to HT29 cells altered the expression of various proteins in HT29 cells (45). In such a way that downregulation of solute carrier (SLC) proteins and peroxiredoxin-6 (PRDX6) in HT29 cells inhibited the normal functioning of mitochondria and negatively affected its ability to withstand stress respectively. Also, HT29 cells entered apoptosis with downregulation of inhibitor of apoptosis protein (IAP3) (57).

Furthermore, a study was established to show the presence of antioxidants, phenols and antiproliferative action of banana compared to the common fruits like cranberry, apple, red grape, strawberry, pineapple, peach, lemon, orange, pear and grapefruit by applying solvent extraction, base digestion and solid-phase extraction methods alongside with measurement of total antioxidant activity using total oxyradical scavenging capacity (TOSC) assay to determine their activities in vitro using human liver-cancer cells (Hep G2) (49). This study recommended that banana targets and inhibits the proteasome selectively in Hep G2, which contributes to its claimed antitumor activity (50). A report ascertains that the consumption of bananas was associated with a low risk of renal cell carcinoma which represents the majority of all cancers of the kidney (51).

Additionally, methanolic extract of banana peel (MEBP) inhibited the re-growth of the ventral prostate gland and seminal vesicles induced in castrated mice by testosterone (52). This further showed that MEBP can inhibit 5alphareductase and might be appropriate in the treatment of benign prostate enlargement (BPH). Micronucleus assays (MN) and single-cell gel electrophoresis (SCGE) assessed the mutagenic activity of Musa paradisiaca fruit and peel extract (53) and it displayed mutagenic activity in the peripheral blood cells (erythrocytes, leukocytes and platelets) of Swiss albino mice. It was also reported that the influence of banana fruit intake was associated with a reduced risk of breast cancer in women (54).

\section{Conclusion}

Musa paradisiaca Linn., a common and extremely valued plant use as food and medicine has been undergoing several pharmacological investigations and been ascertained to be very effective in curing various non-communicable diseases through its medicinally active secondary metabolites. This study is in line with numerous literature in ratifying the pharmacological effect of various extracts of bananas. However, there are no clinical studies yet that can give evidence of its efficacy on humans. Besides, chemical analysis is required to validate the unexplored potentials of this plant. Furthermore, there is a need for isolation of more bioactive constituent(s) so that $M$. paradisiaca can be used for the drug development of possible diseases combating the world.

\section{Acknowledgements}

The author would like to express his gratitude to $\mathrm{Mr}$. Abolaji Samson Olagunju, a post-graduate student, at the Department of Biochemistry, University of Ibadan (UI), Ibadan, Nigeria also Miss Salami Oyiza Khadijat displayed at Nigerian Institute for Trypanosomiasis Research (NITR), Vom, Plateau State, Nigeria for their support in the preparation of this manuscript.

\section{Conflict of interests}

The author declares that there is no conflict of interests.

\section{References}

1. FAO. Production yearbook, FAOSTAT Data, Food and Agriculture Organization of the United Nations, Rome; 2005.

2. Food and Agriculture Organization of the United Nations (FAOSTAT) [Internet]. 2013 November 26 [cited 2020 December 5]. Available from: http://faostat.fao.org/

3. Imam MZ, Akter S. Musa paradisiaca L., and Musa sapientum L.: A phytochemical and pharmacological review. J Appl Pharm Sci. 2011;01:14-20.

4. Yakubu MT, Nurudeen QO, Salimon SS, Yakubu MO, Jimoh RO, Nafiu MO, Akanji MA, Oladiji AT, Williams FE. Antidiarrhoeal activity of Musa paradisiaca sap in Wistar Rats. EvidenceBased Compl Alter Med; 2015:9. https://doi.org/10.1155/2015/683726

5. Ighodaro OM. Evaluation study on Nigerian species of Musa paradisiaca Peels: Phytochemical screening, proximate analysis, mineral composition and antimicrobial activities. Researcher. 2012;4(8):17-20.

6. Omonkhua AA, Onoagbe IO. Evaluation of the long-term effects of Urena lobata root extracts on blood glucose and hepatic function of normal rabbits. J of Toxicol Environ Health Sci. 2011;3:204-13.

7. Rates SM. Plants as a source of drugs. Toxicon. 2001;39:603-13. https://doi.org/10.1016/S0041-0101(00)00154-9

8. Barrett B. Medicinal plants of Nicaragua's Atlantic Coast. Econ Bot. 1994;48:8-20. https://doi.org/10.1007/BF02901375

9. Coe F, Anderson GJ. Ethnobotany of the Sumu (Ulwa) of southeastern Nicaragua and comparisons with Miskitu plant lore. Econ Bot. 1999;53:363-83.

10. Ezekwesili CN, Ghasi S, Adindu CS, Mefoh NC. Evaluation of the anti-ulcer property of aqueous extract of unripe Musa paradisiaca Linn. Peel in Wistar rats. Afr J Pharm Pharmacol. 2014;8:1006-11. https://doi.org/10.5897/AJPP2014.4007

11. Ikpeazu O, Elekwa I, Ugbogu A, Arunsi U, Uche-Ikonne C. Preliminary evaluation of anti-ulcer potential of aqueous extract of fermented unripe Musa paradisiaca in Wistar rats. Am J Biomed Res. 2017;5:17-23.

12. Jang DS, Park EJ, Hawthorne ME, Vigo JS, Graham JG, Cabieses F, Santarsiero BD, Mesecar AD, Fong HH, Mehta RG, Pezzuto JM, Kinghorn AD. Constituents of Musa $\times$ paradisiaca cultivar with the potential to induce the phase II enzyme, quinone reductase. J Agr Food Chem. 2002;50(22):6330-34.

13. Arun KB, Sithara T, Reshmitha TR, Akhil GC, Nisha P. Dietary fiber and phenolic-rich extracts from Musa paradisiaca inflorescence ameliorates type 2 diabetes and associated cardiovascular risks. J Funct Foods. 2017;31:198-207. https://doi.org/10.1016/j.jff.2017.02.001 
14. Palafox-Carlos H, Ayala-Zavala JF, González- Aguilar GA. The role of dietary fiber in the bioaccessibility and bioavailability of fruit and vegetable antioxidants. J Food Sci. 2011;76(1):R6R15. https://doi.org/10.1111\%2Fj.1750-3841.2010.01957.x

15. Tagliazucchi D, Verzelloni E, Bertolini D, Conte A. In vitro bioaccessibility and antioxidant activity of grape polyphenols. Food Chem. 2009;120(2):599-606.

16. Saura-Calixto F, Díaz-Rubio ME. Polyphenols associated with dietary fiber in wine: a wine polyphenols gap. Food Res Int 2007;40(5):613-19. http://doi.org/10.1016/j.foodres.2006.11.005

17. Danlami U, Ijoh JJ, David BM. Phytochemical screening, proximate analysis and anti-oxidant activities of ripe and unripe plantain powder of Musa paradisiaca and Musa accuminata. Am J Biosc Bioeng. 2015;3:87-90. https://doi.org/10.11648/J.BIO.20150305.21

18. Kiin-Kabari DB, Giami SY. Physico-chemical, starch fractions and dietary fibre of biscuits produced from different levels of substitution of wheat flour with plantain flour. Int J Food Sci Nutri Engn. https://doi.org/10.5923/j.food.20150505.03 2015;5:197-202.

19. Annor GA, Asamoah-Bonti P, Sakyi-Dawson E. Fruit physical characteristics, proximate, mineral and starch characterization of FHIA 19 and FHIA 20 plantain and FHIA 03 cooking banana hybrids. SpringerPlus. 2016;5:796.

20. Rajesh N. Medicinal benefits of Musa paradisiaca (Banana). International Journal of Biology Research. 2017;2:51-54.

21. Rao U, Suryati MK, Abdurrazaq M, Ahmad BA, Mohaslinda M, Ali RM. Taxonomical, Phytochemical, and Pharmacological Reviews of Musa sapientum var. paradisiaca. Res J Pharm Technol. 2014;7:1356-61.

22. Mallikarjuna R, Prasad SHKR, Jyothirmayi N. Efficacy of Ripened and Unripened fruit extracts of Musa x Paradisiaca L. (Bontha Cultivar) against human pathogens. Int J Pharm Pharm Sci. 2012;4(1):457-58.

23. Pickup JC. Insulin-pump therapy for type 1 diabetes mellitus. New England Journal of Medicine. 2012;366:1616-24. https://doi.org/10.1056/NEJMc1206221

24. Little A, Feldman E, Hughes RA. Enhanced glycemic control for preventing and treating diabetic neuropathy. Cochrane Database of Systematic Reviews. 2012;6, Article ID CD007543. https://doi.org/10.1002/14651858.CD007543.pub2

25. Rabbani GH, Larson CP, Islam R, Saha UR, Kabir A. Green banana-supplemented diet in the home management of acute and prolonged diarrhea in children: a community-based trial in rural Bangladesh. Trop Med Int Health. 2010;15(10):1132-39. https://doi.org/10.1111/j.1365-3156.2010.02608.x

26. Rabbani GH, Ahmed S, Hossain Iqbal, Islam R, Marni F, Akhtar M, Majid N. Green banana reduces clinical severity of childhood shigellosis: a double-blind, randomized, controlled clinical trial. Pediatr Infect Dis J. 2009;28(5):420-25. https://doi.org/10.1097/INF.0b013e31819510b5

27. Borges MH, Alves DL, Raslan DS, Piló-Veloso D, Rodrigues VM, Homsi-Brandeburgo MI, de Lima ME. Neutralizing properties of Musa paradisiaca L. (Musaceae) juice on phospholipase A2, myotoxic, hemorrhagic, and lethal activities of Crotalidae venoms. J Ethnopharmacol. 2005;98:21-29. https://doi.org/10.1016/j.jep.2004.12.014

28. Kaou AM, Mahiou-Leddet V, Hutter S, Aïnouddine S, Hassani S, Yahaya I, Azas N, Ollivie E. Antimalarial activity of crude extracts from nine African medicinal plants. J Ethnopharmacol. 2008;116:74-83. https://doi.org/10.1016/j.jep.2007.11.001

29. Parmar HS, Kar A. Protective role of Citrus sinensis, Musa paradisiaca and Punica granatum peels against diet-induced atherosclerosis and thyroid dysfunctions in rats. Nutr Res. 2007;27:710-18. http://dx.doi.org/10.1016/j.nutres.2007.09.003

30. Yin X, Quan J, Kanazawa T. Banana prevents plasma oxidative stress in healthy individuals. Plant Foods Hum Nutr. 2008;63:71-76. https://doi.org/10.1007/s11130-008-0072-1

31. Swanson MD, Winter HC, Goldstein IJ, Markovitz DM. A lectin isolated from bananas is a potent inhibitor of HIV replication. J Biol Chem. 2010;285(12):8646-55. https://doi.org/10.1074/jbc.M109.034926
32. Martins FO, Fingolo CE, Kuster RM, Kaplan MA, Romanos MT. Antiviral activity of Musa acuminata Colla, Musaceae. Revista Brasileira de Farmacognosia. 2009;19(3):781-84. https://doi.org/ 10.1590/S0102-695X2009000500022

33. Ho VS, Ng TB. Chitinase-like proteins with antifungal activity from emperor banana fruits. Protein Pept Lett. 2007;14(8):82831. https://doi.org/10.2174/092986607781483750

34. Wanitphakdeedecha R, Nguyen TH, Chen TM. The banana: a surgery training model to refine blade control for Mohs layer removal and skin incisions. Dermatol Surg. 2008;34(8):1088-90. https://doi.org/10.1111/j.1524-4725.2008.34215.x

35. World Health Organization. World Health Day Campaign 2013 Silent Killer, a global public health crisis. Retrieved 2014 March 14. Available from: http/www.who.int/campaign? worldhealth/2013/en/index.index.html

36. James RS, Murray E, Edward DF. Diabetes, hypertension, and cardiovascular disease an update. 2001;37:1053-59. https://doi.org/10.1161/01.HYP.37.4.1053

37. Martinon F. Signaling by ROS drives inflammasome activation. European journal of immunology. 2010;40:616-19. https://doi.org/10.3389/fimmu.2021.732127

38. Steven A. The renin-angiotensin-aldosterone system: pathophysiological role and pharmacologic inhibition. Journal of Managed Care Pharmacy. 2007;13:S9. https://doi.org/10.18553/jmcp.2007.13.s8-b.9

39. AD Daniel. Role of the renin-angiotensin-aldosterone system in vascular remodeling and inflammation: a clinical review. Journal of Hypertension. 2006;24:983-91. https://doi.org/10.1097/01.hjh.0000226182.60321.69

40. Hugo Deneo- Pellegrini et al. Vegetables, fruits and colorectal cancer: A case-control study from Uruguay. Nutrition and Cancer. $1996 ; 25(30): 297-304$ https://doi.org/10.1080/01635589609514453

41. Sun J, Chu Y, Wu X, Liu RH. Antioxidant and antiproliferative activities of common fruits. I Agric Food Chem. 2002;50(25):7449-54. https://doi.org/10.1021/jf0207530

42. Saraswathi NT, Gnanam FD. Effect of medicinal plants on the crystallization of cholesterol. Journal of Crystal Growth 1997;179(3-4):611-17.

43. Parmar HS, Kar A. Protective role of Citrus sinensis, Musa paradisiaca and Punica granatum peels against diet-induced atherosclerosis and thyroid dysfunctions in rats. Nutrition Research. https://doi.org/10.1016/j.nutres.2007.09.003

44. Laura L, Ghrairi F, Arem AE, Sghaeir W, Felah ME, Salem HB, Sriha B, Achour L. Attenuation of histopathological alterations of colon, liver and lung by the dietary fiber of barley Rihane in azoxymethane-treated rats. Food Chem. 2014;149:271-76.

45. Arun KB, Aravind M, Reshmitha TR, Sithara T, Nisha P. Musa paradisiaca inflorescence induces human colon cancer cell death by modulating cascades of transcriptional events. Journal of the Royal Society of Chemistry, Food Funct. 2018;9:511-24. https://doi.org/10.1039/c7fo01454f

46. Abaza MS, Al-Attiyah R, Bharadwaj R, Abbadi G, Koyippally M, Afzal M. Syringic acid from Tamarixaucheriana possesses antimitogenic and chemosensitizing activities in human colorectal cancer cells. Pharm Biol. 2013;51(9):1110-24. https:// doi.org/10.3109/13880209.2013.781194

47. Deng H, Fang Y. The three Catecholics benserazide, catechol, and pyrogallol are gpr35 agonists. Pharmaceuticals. 2013;6(4):500-09. https://doi.org/10.3390/ph6040500

48. Whent M, Huang H, Xie Z, Lutterodt H, Yu L, Fuerst EP, Morris CF, Yu LL, Luthria D. Phytochemical composition, antiinflammatory, and anti-proliferative activity of whole wheat flour. I Agric Food Chem. 2012;60(9):2129-35. https://doi.org/10.3390\%2Fijms16023512

49. Sun J, Chu Y, Wu X, Liu RH. Antioxidant and antiproliferative activities of common fruits. I Agric Food Chem. 2002;50(25):7449-54

50. Kazi A, Urbizu DA, Kuhn DJ, Acebo AL, Jackson ER, Greenfelder GP, Kumar NB, Dou QP. A natural Musaceae plant extract inhibits proteasome activity and induces apoptosis selectively 
in human tumor and transformed, but not normal and nontransformed cells. Int J Mol Med. 2003;12(6):879-87. https://doi.org/10.1002/ijc.20577

51. Rashdkhani BP, Lindblad AW. Fruits vegetables and risk of renal cell carcinoma. A prospective study of Swedish women. Int J Cancer. 2005;113:451-55. https://doi.org/10.1271/bbb.80770

52. Akamine K, Koyama T, Yazawa K. Banana peel extract suppressed prostate gland enlargement in testosterone-treated mice. Biosci Biotechnol Biochem. 2009;73(9):1911-14. https://doi.org/10.4238/vol7-3gmr462

53. Andrade CU, Perazzo FF, Maistro EL. Mutagenicity of the Musa paradisiaca (Musaceae) fruit peel extract in mouse peripheral blood cells in vivo. Genet Mol Res. 2008;7(3):725-32. https://doi.org/10.1002/ijc.24358

54. Zhang CX, Ho SC, Chen Y, Fu J, Cheng S, Lin F. Greater fruit and vegetable intake is associated with a lower risk of breast cancer in Chinese women. Int J Cancer. 2009;125:181-88. http:// doi.org/10.1002/ijc.24358

55. Sarah MA, Osama MA, Sanaa MA, Hessah MA, Kamal AA, Mohamed A. Antihyperglycemic effects and mode of actions of Musa paradisiaca leaf and fruit peel hydroethanolic extracts in Nicotinamide/Streptozotocin-induced diabetic rats. EvidenceBased Complementary and Alternative Medicine. 2020;2020, Article ID: 9276343. https://doi.org/10.1155/2020/9276343

56. Anu K, Lalit K, Navpreet K, Rakesh G, Randhir S. Therapeutic agents for the management of atherosclerosis from herbal sources. Beni-Suef University Journal of Basic and Applied Sciences. https://doi.org/10.1016/j.bjbas.2016.02.004
57. Arun KB, Aravind M, Reshmitha TR, Sithara T, P Nisha. Musa paradisiaca inflorescence induces human colon cancer cell death by modulating cascades of transcriptional events. Food Funct. 2018;9:511. https://doi.org/10.1039/c7fo01454f

58. Mohammad ZI, Saleha A. Musa paradisiaca L. and Musa sapientum L.: A Phytochemical and Pharmacological Review. Journal of Applied Pharmaceutical Science. 01(05);2011:14-20.

59. Rao US, Ado B, Mohd K, Muhammed A, Zin T. Phytochemical screening, the antioxidant activity of pure syringin in comparison to various solvents extracts of Musa paradisiaca (banana) (fruit and flower) and total phenolic contents. Int J Pharm Pharm Sci. 7(5);2015:242-47.

\section{Additional information}

Peer review information: Plant Science Today thanks Sectional Editor and the other anonymous reviewers for their contribution to the peer review of this work.

Reprints and permissions information is available at

https://horizonepublishing.com/journals/index.php/PST/open_access_policy

Publisher's Note: Horizon e-Publishing Group remains neutral with regard to jurisdictional claims in published maps and institutional affiliations.

To cite this article: Adesola $\mathrm{R} O$. The pharmacological potentials of Musa paradisiaca Linn.. Plant Science Today. 2021;8(4):1091-1097. https://doi.org/10.14719/pst.2021.8.4.1066

Plant Science Today, published by Horizon e-Publishing Group, is covered by Scopus, Web of Science, BIOSIS Previews, Clarivate Analytics, etc. See https://horizonepublishing.com/journals/index.php/PST/indexing_abstracting 